\title{
MULTIPLE VIEWS OF PARTICIPATORY DESIGN Henry SANOFF
}

Received: 14.11.2006

Keywords: participation; participatory democracy; deliberative democracy; participatory design; strategic plan.

\section{HISTORICAL BACKGROUND}

Citizen participation in community decision-making can be traced as far back as Plato's Republic (Plato and Grube, 1992). Plato's concepts of freedom of speech, assembly, voting, and equal representation have evolved through the years to form the basis upon which the United States was established. Some historians support the notion that Americans have always wanted to be part of decisions affecting their lives. Billington (1974) contends that freedom and the right to make decisions on the early American frontier was the shaping force in grass roots democracy, i.e., people's right to participate. As many frontier villages grew in population it became increasingly difficult for every citizen to actively participate in all community decisions. To fill the void in the decision making process, people began to delegate their involvement to a representative, which grew into the system of selecting officials by public elections, and the increase of volunteer associations and organizations (de Tocqueville, 1959). Although public participation can be approached and defined in many different ways, this discussion is concerned with participation aimed at issues involving community decision-making.

Community consciousness in the 1960s led to direct involvement of the public in the definition of their physical environment and an increased sense of social responsibility constituted a new movement. Following this movement, community design centers aiming to offer design and planning services to enable the poor to define and implement their own planning goals, were established in the United States and the United Kingdom. They were influenced by Paul Davidoff's advocacy model of intervention. Similarly, many design and planning professionals rejected traditional practice (1965). Instead they fought against urban redevelopment, advocated for the rights of poor citizens, and developed methods of citizen participation. Government financial aid programs that encouraged the participation of citizens in community improvement programs supported 
this movement. With these programs, people outside the professions were allowed to make decisions about planning and financing. Citizens were given the right to participate in planning and implementation processes through grants and technical assistance (Sanoff, 2005). Volunteer citizen participation continues to be one of the key concepts in American society.

In northern Europe, participatory design grew out of work beginning in the early 1970s in Norway when computer professionals, union leaders and members of the Iron and Metalworkers Union strove to enable workers to have more influence on the introduction of computer systems in the workplace (Winograd, 1996; Spinuzzi, 2005). Several projects in Scandinavia set out to find the most effective ways for computersystem designers to collaborate with worker organizations to develop systems that most effectively promoted the quality of work life. Pelle Ehn describes a design philosophy called the "tool perspective," whereby new computer-based tools should be designed as an extension of the traditional practical understanding of tools and materials used within a given craft of profession. "Design must therefore be carried out by the common efforts of skilled, experienced users and design professionals. Users possess the needed practical understanding but lack insight into new technical possibilities. The designer must understand the specific labor process that uses a tool" (Ehn, 1992, 112). In Denmark, the MUST-method, a method of participatory design that creates the computer support for the production and airing of radio programs identifies strategic analysis and visioning as the main design activities (Bodker et al., 2004).

In an alliance called Computer Professionals for Social Responsibility (CPSR) participatory design is described as an approach to the assessment, design, and development of technological and organizational systems that places a premium on the active involvement of workplace practitioners in design and decision-making processes.

The International Association for Public Participation (IAP2), founded in 1990, seeks to promote and improve the practice of public participation in relation to individuals, governments, institutions, and other entities that affect the public interest in nations throughout the world. Core values for the practice of pubic participation include that the public should have a say in decisions about actions that could affect their lives and that their contribution will influence the decision. Participants should be provided with the information they need to participate in a meaningful way and be informed how their input affected the decision.

The Participatory Geographies Working Group (PyGyWG) based in the UK, reflects a surge of interest in the study and application of participatory research methods such that geographic research should have benefits for those affected by the social, economic and environmental issues, which are at its heart. A range of participatory principles underpins participatory geographies, such as a focus on empowerment and collective action where participants learn from their engagement in the process. They believe that participatory work should be proactively inclusive with practitioners actively attempting to include and seek out people who are often ignored or do not take part in community development or research processes. Participatory geographers, therefore, often seek to work in bottom-up ways with the goal of actively engaging and benefiting groups outside academia so that traditional barriers between 'expert researcher' and 'researched community' are broken down (PyGyWg, 2006). 


\section{PARTICIPATORY DEMOCRACY}

Participatory design is an attitude about a force for change in the creation and management of environments for people. Its strength lies in being a movement that cuts across traditional professional boundaries and cultures. The activity of community participation is based on the principle that the environment works better if citizens are active and involved in its creation and management instead of being treated as passive consumers (Sanoff, 2000). Democratic theory has always stressed citizen participation in public decision-making. With few exceptions, however, democratic theory has traditionally encouraged 'low quality citizen action by making a fetish out of only one form of political participation-voting' (Pranger, 1968, 30). Despite the insistence on 'citizen rule' in the ideology of democracy, large segments of the population in all modern nations are in reality powerless to significantly affect the political decisions, policies, and actions of their societies. The concept of participatory democracy, which emerged in the 1960s, was a rediscovery of traditional democratic philosophy (Olsen, 1982). The central features of a participatory democracy can be distilled into the following definition:

In a participatory democracy, collective decision-making is highly decentralized throughout all sectors of society, so that all individuals learn participatory skills and can effectively participate in various ways in the making of all decisions that affect them. Particularly crucial in this conception of participatory democracy is the insistence that full democratization of decision-making within all local and private organizations is a necessary prerequisite for political democracy at the national level. It has been argued that a participatory democracy leads to persistent conflict, eventual alienation from the political system, and unnecessary and expensive delays (Rosner, 1978). This argument holds that a majority of the population, who do not now actively participate, hold attitudes that are intolerant of any deviation from the cultural norm. Consequently, if more of these people are drawn into active political life, these attitudes will influence the political process such that they will affect the survival of a democracy.

In recent years, however, the idea of participatory democracy has invaded numerous areas of social life, including industry, neighborhoods, and race relations. Most evident has been the rapid expansion of relatively formalized programs for promoting participation in community programs and government (Cahn and Passett, 1971; Lind, 1975). The development of a communities' potential through collaborative problem solving is described by social scientists as participatory action research (PAR), where citizens are empowered to effect social change by controlling the knowledge produced by participation (Whyte, 1991).

Is participatory democracy a realistic direction for our future, was a question asked in a study in five U.S. cites-Birmingham, Dayton, Portland, San Antonio, and St. Paul, in ten comparison cities, and in seventy participation projects throughout the country over a two year period (Thomson et al., 1994). The findings revealed a positive relationship between participation and support of the system, trust in government officials, and tolerance toward other's points of view. The stronger the participation system and the more people who participate, the greater the support for democratic values. 


\section{DELIBERATIVE DEMOCRACY}

Carson (2003) recognizes the deficiencies of representative government and proposes to engage in deliberation, or build deliberative capacity whereby citizens' work towards collective outcomes. She describes her approach as deliberative governance, which advocates democratic problem-solving initiatives. Proponents of citizen deliberation argue that participation in deliberative forums has a positive impact on citizens' attitudes and behaviors. The potential benefits of deliberation include more informed and reflective judgments, a greater sense of political efficacy, and an increase in the frequency of political action (Bohman, 1996; Cohen, 1997; Gastil, 2000). Sirianni and Friedland (2005) refer to a deliberative democracy whereby citizens and their representatives deliberate about community problems and solutions through reflection and judgment, with the willingness to understand the values and interests of others in a search for mutually acceptable solutions. Deliberative democracy introduces a different citizen voice than that associated with public opinion and simple voting. It seeks a citizen voice capable of recognizing other group's interests, appreciating the need for trade-offs, and generating a sense of common ownership. The practical question for design and planning professionals is how best to be deliberative within conflictual, adversarial settings (Forester, 1999).

Underpinning a deliberative democracy is Atlee's (2003) concept of collective intelligence $(\mathrm{CI})$, which is based on the ability of groups to sort out their collective experience in ways that help to respond appropriately to circumstances - especially when faced with new situations. Atlee (2003, 53) describes collective intelligence as a shared insight that comes about through the process of group interaction, particularly where the outcome is more insightful and powerful than the sum of individual perspectives. Collective intelligence has been suggested as being partly responsible for favorable participatory design outcomes (Fischer et al., 2005).

To increase the effectiveness of our democracy, Atlee advances the idea of Citizen Deliberative Councils (CDC), which are small face-to-face groups of diverse citizens that convene for short periods of time to consider some public concern. Deliberation, states Atlee, is a form of dialogue with the intention of producing decisions, policies, recommendations or collective action. Deliberation involves a careful consideration of an issue, examining the facts, viewpoints and consequences related to it. Unlike an open participatory forum, a CDC is an organized group of people selected such that their collective diversity reflects the diversity of the larger population from which they were drawn. Unlike public hearings, which are often aimed at airing views, citizen deliberative councils are small, usually between ten to fifty people, and generate a specific product such as a recommendation, which would generate further community dialogue.

\section{SENSE OF COMMUNITY}

Building a participatory democracy also means building an increased sense of community among the population at large. When people have a strong sense of community, they are more likely to respond positively to efforts to solve community problems, and will be willing to contribute their time and resources to meeting community needs (Morris, 1996). The process is a stabilizing rather than a destabilizing force. Increased participation efforts do bring in more people who initially have a lower sense of community than is typical for those who are politically involved. But these efforts also 
develop the participants' sense of community for as long as they remain involved (Thomson et al., 1994). Planners and architects facilitating a collaborative design process is described as "co-design" by King (1983), with such benefits as creating events that allow for social interaction and developing a sense of community through face-to-face interactions, and publicly affirming community values.

Similarly, the unique qualities of places where planning and development occur can play a critical role in the process as well (Manzo, 2006). Citizens' attachment to places in their community can help to inspire action because people are motivated to protect and improve places that are meaningful to them. Sense of community has been linked to place attachment at the individual and community scale. Rivlin's (1987) study of a Brooklyn neighborhood found that attachment to the neighborhood served as a precondition for the development of a sense of community among neighbors. Both sense of community and place attachment are linked to participation, consequently sense of community has become a key planning goal (Morris, 1996; Perkins, Brown and Taylor, 1996). Other studies in participation conducted during the past decade have referred to such benefits as citizen empowerment, increasing social capital and promoting a sense of community (Guy, 2002).

The effectiveness of community organizations, social relationships and mutual trust is referred to as social capital. It is a measure of the social networks in a community with such indicators as civic education, community leadership, volunteerism, community pride, government performance, and capacity for cooperation (Bens, 1994). Therefore, social capital, along with place attachment can be perceived of as community assets that can be created through community participation (Kretzmann and McKnight, 1993). A community organizing approach described as Asset Based Community Development (ABCD) sees citizens as assets and as co-creators of their community. Citizens discover, map and mobilize the assets that are within the people in the community, as well as informal associations and formal organizations. Active community participation is key to building an empowered community. Empowerment is where people, organizations and communities have control over their affairs (Rapoport, 1987). Communities seeking to empower themselves can build active citizen participation by welcoming it, creating valuable roles for each person to play, actively reaching out to build inclusive participation, and creating and supporting meaningful volunteer opportunities. Studies of empowerment demonstrate that such power is achieved on the strength of interpersonal relationships among those working towards a common goal (Perkins, 1995). Shiffman states that, "community development is not simply rebuilding...it is... about social and economic justice" (PICCED, 2000). Speer and Hughey (1995) claim that shared values and strong emotional ties are more effective bonding mechanisms than reactions to community issues alone.

\section{PARTICIPATION OBJECTIVES}

Clearly, participation is a general concept covering different forms of decision-making by a number of involved groups (Wulz, 1986). Participation can be addressed effectively if the task of participation is thought of in terms of what is to be accomplished when there is an acknowledged need to involve community members. Conceptualizing the issue means asking simple questions: who, what, where, how, and when? 
- Who are the parties to be involved in participation?

- What should be performed by the participation program?

- Where should the participation road lead?

- How should people be involved?

- When in the planning process is participation desired?

The planning that accompanies the development of any participation event should first include a determination of objectives, such as, to generate ideas, to identify attitudes, to disseminate information, or to review a proposal? The list of possible participation objectives will differ from time to time and from issue to issue. Once the objectives of community participation are stated, it becomes clear that participation is perceived according to the type of issue and people involved. If differences in perception and expectations are not identified at the outset, and realistic objectives are not made clear, the expectations of those involved in the participation program will not have been met, and they will become disenchanted. Planning for participation requires that participation methods be matched to the objectives, and the appropriate method be selected. The professional's role is to facilitate the community's ability to reach decisions about aspects of their environment through an easily understood process. Facilitation is a means of bringing people together to determine what they wish to do and helping them find ways in deciding how to do it. Facilitation can also include the use of a variety of techniques whereby people who are not professionally trained can organize themselves to create a change in the environment

Citizen participation has a broad value to community life. In a general sense, the purpose of citizen participation is to inform the public, get the public's reactions regarding the proposed actions or policies, and engage in problem solving to come up with the best solutions for everyone (Creighton, 1994). What adds legitimacy to a decision is not only the substance of the decision but also the perception that the process by which the decision was made was fair, open, and democratic. This is true, even if some individuals or groups do not agree with the final decision. History shows that better public decisions happen when the public is involved in the decision-making process. People have more ownership for the program's success if they have had a part in creating it. They also hold a key element that only comes from their experience. Decision-makers need the voice of experience to line up with facts and figures produced by studies.

\section{STRATEGIC PLANNING AND VISIONING}

Participation does not imply that there is no longer a role for municipal authorities. It only means that a dialogue is necessary between citizens and public officials regarding needs and resources to meet needs (Sanoff, 2000). This dialogue may take the form of a vision statement implemented by a strategic plan.

Visioning is a process that seeks to 'create living, useful guides for actions intended to position the community for the future' (Thomas et al., 1988). A community group is ready for a visioning process when there is some dissatisfaction with the present situation, when there is a sense that they must pursue a different future than one suggested by the present approach. Participants in a visioning process are asked to contribute ideas at the 
beginning, before experts and administrators narrow the range of options. Visioning reinvigorates citizenship in communities where it is used.

A visioning process is usually the central element in a community's strategic plan. Participants are asked to think about how the community should be and find ways to identify, strengthen and work toward a community vision. Such information helps the visioning participants understand the context and constraints under which they are operating. Although specialists may carry out specific policies and recommendations, citizens remain responsible for the framework within which decisions are made. The shared vision belongs to the group rather than to any one individual.

Strategic planning is a management technique borrowed from the private sector. Poister and Streib (1989) report that $60 \%$ of cities with populations of more than 25,000 use some form of strategic planning. Basically, strategic planning is an organized effort to produce decisions and actions that shape and guide what a community is, what it does, and why it does it. Strategy is the act of mobilizing resources towards goals. It includes setting goals and priorities, identifying issues and constituencies, developing an organization, taking actions and evaluating results (Checkoway, 1986). Strategic planning requires information gathering, an exploration of alternatives, and an emphasis on the future implications of present decisions. It can facilitate communication and participation, accommodate divergent interests and values, and foster orderly decision-making and successful implementation.

A strategic plan is a method of developing strategies and action plans necessary to identify and resolve issues. The challenge in creating a plan is to be specific enough to be able to monitor progress over time. To be usable, a strategic plan should have built-in

flexibility to allow for revisions to occur, as new opportunities become apparent. Strategic planning is action-oriented, considers a range of possible futures, and focuses on the implications of present decisions and actions in relation to that range (Bryson, 1988). The development of a strategic plan requires the creation of a vision statement to provide suitable guidance and motivation for the ensuing process. The vision should emphasize purposes arrived at through group sessions in order to establish a common reference point for the broad objectives of the community. It outlines the key areas of concern within the community and will help people make decisions that support that vision.

Making community participation work means a commitment on the part of the local government division or community agency initiating the process. Local governments seeking citizen participation must want, and be willing to accept, citizen input (Moore and Davis, 1997). When participation is successful, the following are some of the benefits the community receives (Creighton, 1994).

- Improved quality of decisions

- Minimizing cost and delays

- Consensus building

- Increased ease of implementation

- Avoiding 'worst-case' confrontations

- Maintaining credibility and legitimacy 
- Anticipating public concerns and attitudes

- Developing public expertise and creativity.

\section{PROMOTING PARTICIPATION}

Being intentional about how a participation program is designed helps to ensure that it will involve the public in the places where their input is most needed. Good planning for community participation requires careful analysis. Although it is critical to examine goals and objectives in planning for participation, there are various techniques that are available, each of which performs different functions. In the last several decades, there have been numerous efforts to accumulate knowledge about various participation techniques, as well as the function that these techniques perform. Community surveys, review boards, advisory boards, task forces, neighborhood and community meetings, public hearings, publicinformation programs, and interactive cable TV, have all been used with varying degrees of success, depending on the effectiveness of the participation plan. Because community participation is a complex concept, it requires considerable thought to prepare an effective participation program.

Informing a large audience about proposals, generating interest, or securing approval can take the form of a community meeting also referred to as a public hearing or a public forum. Public meetings allow community leaders to present project information at any time during the process. The tight structure of such meetings, however, does not permit ample time for discussion. Although referred to as community participation, only the most aggressive personalities tend to participate and often dominate the discussion (Creighton, 1994). Public reactions in open meetings are often taken by a vote through a show of hands. The key to making community design work effectively is a range of techniques for enabling professionals and citizens to creatively collaborate, where voting is replaced by consensus decision-making.

A community in Tennessee encountered a lack of involvement and a certain degree of apathy within the community that was not initially anticipated when the strategic plan was developed (Reid, 2000). Consequently, there was a gap between project needs and the human resources available to meet them. It became evident that public participation is a powerful force that can significantly impact activities within the community. As a result, community leaders focused on maintaining direction despite declining participation. One example of this need to maintain direction became clear while examining the feasibility of a county community housing development organization. Negative preconceptions about its purpose and role resulted in poor attendance at subcommittee meetings. Among the steps taken by the community organizers to address lack of involvement and improve public awareness were these:

- Establishing a policy of inclusiveness

- Holding open meetings

- Making speeches to community groups

- Obtaining public input

- Making public announcements

- Holding face-to-face meetings 
- Conducting progress surveys

\section{CONSENSUS}

The idea of consensus has been evident since ancient history, in the notion of consensus gentium, the Latin phrase for 'agreement of people' (Gove and Merriam-Webster, 1986). Contemporary views of consensus have evolved from educational and political philosophy. In the political world, consensus usually means that a significant majority of people supports a particular proposal. In small group situations consensus is usually thought of as unanimity in agreement.

There is a dark side of consensus in that it protects the system from change and results in homogeneity (Muldoon, 1996). The view is that agreement oriented process have achieved their goal by pressuring people toward an uneasy unanimous goal, that they are a manipulated form of consent. The pressure for consensus has the potential to inhibit the argumentative process as well as silence those who are marginalized. "Real" consensus, according to Atlee, comes about as a result of "comfortably agreed-to outcomes achieved through real dialogue," where differences are creatively explored $(2003,238) . "$ Through shared discovery, where people listen to each other and identify points of agreement and disagreement, a process of co-sensing is achieved.

On the grounds of equal participation and the development of consensus, Connolly (1969) coined 'the arena theory', which involves an ultimate appeal to the notion of consensus. This theory advocates the exchange of expert and experiential knowledge. The assumption of the arena theory is that there is at least one agreeable outcome to which all parties come to a consensus. However, there must be a willingness of groups to accommodate one another. Such consensus cannot be achieved in isolation. Through the iterative process of social learning and through the equality framework of the arena theory, a consensus can develop.

Group ownership is considered a significant strength in furthering ideals of consensus. As Avery $(1981,20)$ states, 'Group ownership acknowledges that new concepts are developed through the process of members responding to previous contributions of other members'. With group ownership of ideas, it is the idea itself, not the presenter that is criticized. Through this process, all participants are involved in developing ideas and decisions where consensus has to do with shared insight or awareness. When faced with complex problems and diverse interests, collaborative decision-making embraces face-to-face interaction and encourages creativity, open communication, broad participation and agreement. Designing a clear, well-managed collaborative process can lead to agreement where all participants are likely to receive wide community support during implementation.

\section{CONCLUSION}

In organizational development, participation refers to an approach that is rooted in trust, intimacy, and consensus. This relationship described by William Ouchi (1981), as Theory Z, is where the decision-making process is typically a consensual, participative one. Egalitarianism is a central feature of Type $\mathrm{Z}$ organizations. It implies that each person can apply discretion and can work autonomously without close supervision, because they 
are to be trusted. This feature accounts for the high levels of loyalty and productivity in Type $\mathrm{Z}$ organizations.

Similarity in approaches between community design and participatory design, which has its origins in Scandinavia, are equally evident since both stress the importance of the user and the collaborative learning process with designer/ planners. Advocates of participatory action research distinguish between research for the people and research by the people, where participatory methods have had parallel developments in such fields as public health, resource management, adult education, rural development, and anthropology (Whyte, 1991). Research is seen not only as a process of creating knowledge, but simultaneously, as education and development of consciousness, and of mobilization for action.

Community participation in design and planning, as a movement, emerged from a growing realization that the mismanagement of the physical environment is a major factor contributing to the social and economic ills of the world and that there are better ways of going about design and planning. Consequently, how to make it possible for people to be involved in shaping and managing their environment is what the community design movement has been exploring over the past few decades. Starting with designers and planners working with, instead of against, community groups, it has grown rapidly to include a new breed of professional in a variety of partnership programs involving the public sector with developers and financial institutions and working closely with the volunteer sector. In such cases, it has become evident that the planning that accompanies the development of any participation program should first include a determination of objectives, such as, is the participation intended to generate ideas, identify attitudes, disseminate information, measure opinion, resolve some conflict, or review a proposal? Experiences in the participation process show that the main source of user satisfaction is not the degree to which a person's needs have been met, but the feeling of having influenced the decisions. Therefore, the re-emergence of the ideal of a participatory democracy at the national level is effective only if people have been prepared for participation at the local level, such as the workplace and community, since it is at this level that people learn selfgovernance.

\section{REFERENCES}

ATLEE, T. (2003) The Tao of D emocracy: U sing Co-Intelligence to Create a W orld that W orks for All, The Writers Collective, Cranston, RI.

AVERY, M. (1981) Building U nited Judgement: A H andbook for Consensus D ecision M aking, The Center for Conflict Resolution, Madison, WI.

BENS, C.K. (1994) Effective Citizen Government: How To Make It Happen, N ational Civic Review, 83(1); 32-38.

BILLINGTON, R.A. (1974) A merican's Frontier H eritage, Holt, Rinehart and Winston, New York.

BODKER, K., KENSING, F. and SIMONSEN, J. (2004) Participatory IT D esign: D esigning for Business and W orkplace Realities, MIT Press, Cambridge.

BOHMAN, J.F. (1996) Public D eliberation: Pluralism, Complexity, and D emocracy, MIT Press, Cambridge, MA. 
BRYSON, J.M.(1988) Strategic Planning for Public and N onprofit O rganizations, Jossey-Bass, San Francisco, CA.

CAHN, E.S. and PASSETT, B.A.(1971) Citizen Participation: Effecting Community Change, Praeger, New York.

CARSON, L. (2003) Building sustainable democracies, paper presented at N ow We A re People Conference, University of Technology, Sydney, Australia.

CHECKOWAY, B. (1986) Building citizen support for planning at the community level, Interdisciplinary Planning: A Perspective for the Future, Center for Urban Policy Research, New Brunswick, NJ.

COHEN, J. (1997) Deliberation and democratic legitimacy, in J.F. Bohman and W. Rehg (eds.), D eliberative D emocracy: Essays on Reason and Politics, MIT Press, Cambridge, MA.

CONNOLLY, W.E. (1969) The Bias of Pluralism, Atherton Press, New York.

CREIGHTON, J.L. (1994) Involving Citizens in Community D ecisions M aking: A Guidebook, Program for Community Problem Solving, Washington, DC.

DAVIDOFF, P. (1965) Advocacy and pluralism in planning, Journal of the A merican Institute of Planning (31) 331-338.

De TOCQUEVILLE, A. 1959) D emocracy in A merica. Vintage Books, New York.

EHN, P. (1992) Scandinavian design: On participation and skill, in P. Adler and T. Winograd (eds.) U sability: Turning Technologies into T ools, Oxford University Press.

FISCHER, G., GIACCARDI, E., EDEN, H., SUGIMOTO, M. and YE, Y. (2005) Beyond binary choices: Integrating individual and social creativity. H uman-Computer Studies (63) 482-512.

FORESTER, J. (1999) The Deliberative Practitioner: Encouraging Participatory Planning Processes, MIT Press, Cambridge, MA.

GASTIL, J. (2000) By Popular D emand: Revitalizing Representative D emocracy Through D eliberative Elections, University of California Press, Berkeley.

GOVE, P.B. and MERRIAM-WEBSTER (1986) W ebster's N ew International Dictionary, Merriam-Webster, Springfield, MA.

GUY, B. (2002) Community D esign Primer, Environmental Leadership Program, available at http:// www.elpnet.org

IAP2. (2006) http://www.iap2.org/displaycommon.cfm?an=4

LIND, A.(1975) The future of citizen participation, The Futurist; 316-28.

KING, S. (1983) Co-D esign: A Process of D esign Participation, Van Nostrand Reinhold, New York.

KRETZMANN, J.P. and McKNIGHT, J.L. (1993) Building Communities from the Inside O ut: A Path Toward Finding and M obilizing a Community's A ssets, ACTA, Chicago.

MANZO, L. A. and PERKINS, D. D. (2006) Finding common ground: The importance of place attachment to community participation and planning, Journal of Planning Literature, 20 (4); 336-350. 
MOORE, C.N. and DAVIS, D. (1997) Participation Tools for Better LandU se Planning, Local Government Commission/Center for Livable Communities, Sacramento, CA.

MORRIS, E.W. (1996) Community in theory and practice: A framework for intellectual renewal, Journal of Planning Literature (11)127-150.

MULDOON, B. (1996) The H eart of Conflict, Putnam Publishing Group.

OUCHI, W. (1981) Theory Z: How American Business Can Meet the Japanese Challenge, Addison- Wesley, Boston, MA.

OLSEN, M. E. (1982) Participatory Pluralism: Political Participation and Influence in the U nited States and Sweden, Nelson Hall, Chicago, IL.

PERKINS, D.D. (1995) Speaking truth to power: Empowerment ideology as social intervention and policy, A merican Journal of Community Psychology 23 (5); 765-794.

PERKINS, D.D., BROWN, B.B. and TAYLOR, R.B.(1996) The ecology of empowerment: Predicting participation in community organizations, Journal of Social Issues, 52 (1); 85-110.

PICCED. Pratt Institute Center for Community and Environmental Development (2000) http: / / www.picced.org/basics/ overview.htm

PLATO, and GRUBE, G.M.A. (1992) Republic, Hackett Publishing Company, Indianapolis, IN.

POISTER, T. H. and STREIB, G. (1989) Management tools in municipal government: Trends over the past decade, Public A dministration Review (49) 244.

PRANGER, R. J. (1968) The E clipse of Citizenship. New York: Holt Rinehart \& Winston.

PyGyWg (2006) Participatory Geographies W orking Group, http: / / www. geog.leeds.ac.uk/research/pygywebsite/about.html

RAPOPORT, A. (1987) Terms of empowerment exemplars of prevention: Towards a theory for community psychology, A merican Journal of Community Psychology, 15; 121-143.

REID, J.N. (2000) H ow People Power Brings Substantial Benefits to Communities, Washington, DC: USDA Rural Development Office, Office of Community Development.

RIVLIN, L. (1987) Group membership and place meanings in an urban neighborhood. Journal of Social Issues, 38(3); 75-93.

ROSENER, J. (1978) Matching method to purpose: The challenges of planning citizen participation activities, in Citizen Participation in A merica, by S. Langton (ed.), Lexington Books, New York.

SANOFF, H. (2000) Community Participation M ethods in D esign and Planning, Wiley, New York.

SANOFF, H. (2005) Origins of community design, Progressive Planning (166) 14-17.

SIRIANNI, C. and FRIEDLAND, L. (2005) D eliberative D emocracy, available at http:/ / www.cpn.org/tools/dictionary/deliberate.html 
SPEER, P.W. and HUGHEY, J. (1995) Community organizing: An ecological route to empowerment and power, A merican Journal of Community Psychology, 23(5); 729-48.

SPINUZZI, C. (2005) The methodology of participatory design, Technical Communication 52(2); 163-174.

THOMAS, R.L., MEANS, M.C. and GREIVE, M.A. (1988) Taking Charge: $\mathrm{H}$ ow Communities are Planning their Futures, International City Management Association, Washington, DC.

THOMSON, K., BERRY, J.M. and PORTNEY, K.E. (1994) Kernels of D emocracy, Lincoln Filene Center at Tufts University, Boston, MA.

WHITE, S. A., NAIR, K. S. and ASCROFT, J. (1994) Participatory Communications: W orking for Change and D evelopment, Sage Publications, Thousand Oaks, CA; 279.

WHYTE, W.F. (1991) Participatory A ction Research, Sage Newbury Park, CA.

WINOGRAD, T. (1996) Bringing D esign to Software, Addison-Wesley, Boston, MA.

WULZ, F. (1986) The concept of participation, D esign Studies (7) 153-162.

Alındı: 14.11.2006

Anahtar Sözcükler: katılım; katılımcı demokrasi; müzakereci demokrasi; katılımcı tasarım; stratejik planlama.

\section{KATILIMCI TASARIM ÜZERINNE ÇOK YÖNLÜ DÜŞÜNCELER}

Katılımcı tasarım, insan için çevreler yaratılması ve işletilmesinde kullanılan dönüştürücü güçle ilgili bir tutumdur. Bugün katılımcı tasarım süreçleri, kentsel tasarım ve planlamaya olduğu kadar, endüstri ve bilişim teknolojisi alanlarına da uygulanmaktadır. Kentlilerin ortak sonuçlar için vizyon geliştirme, stratejik planlama yapma ve müzakereci demokrasi ortamı oluşturma çalışmaları, bunların tümü de bir "topluluk'un ne olduğunu, ne yaptığını ve bunu neden yaptığını biçimlendiren ve yönlendiren eylemleri hedefler. Bunların da ötesinde, son on yıldır yürütülen katılımcı çalışmalar, toplumsal sermayenin zenginleşmesi ve topluluk duygusu paylaşımının artırılması gibi kentlileri güçlendirici (citizen empowering) yararlar ortaya koymaktadır.

\section{ABSTRACT}

Participatory design is an attitude about a force for change in the creation and management of environments for people. Today participatory design processes are being applied to urban design and planning as well as to the fields of industrial and information technology. Citizen's working towards collective outcomes, has been described as visioning, strategic planning, and deliberative democracy, all aimed at actions that shape and guide what a community is, what it does, and why it does it. Overall, studies in participation conducted during the past decade have referred to such benefits as citizen empowerment, increasing social capital and promoting a sense of community. 